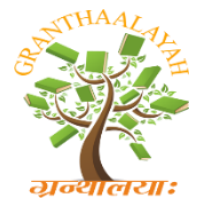

\author{
GRANTHAALAYAH \\ A knowledge Repository
}

INTERNATIONAL JOURNAL OF RESEARCH - 口涪回

Science

\title{
DETERMINANTS AND TECHNICAL EFFICIENCY OF MAIZE PRODUCTION IN MUNA DISTRICT OF SOUTHEAST SULAWESI
}

\author{
Laode Geo ${ }^{* 1}$ \\ ${ }^{* 1}$ Department of Agribusiness, Faculty of Agriculture, Halu Oleo University, Kendari, Indonesia
}

\begin{abstract}
This study aimed to assess (1) factors affecting the production of maize farming and (2) the technical efficiency of maize farming. The study was conducted at Bone Kacintala subdistrict, Muna district, Southeast Sulawesi. The study location was selected purposively as it was production center of maize farming. Respondents consisted of 32 farmers who were taken using simple random method. The data consisted of primary and secondary data. The data were analyzed using Cobb-Douglas production function and Stochastic Frontier. The results showed that the level of technical efficiency of maize farming was 0.72 on average, which was efficient and there was still an opportunity of 28 percent to increase the technical efficiency. Land size, seed and fertilizer had positive and significant effect on maize production.
\end{abstract}

Keywords: Factors; Maize; Production Sulawesi; Technical Efficiency.

Cite This Article: Laode Geo. (2020). "DETERMINANTS AND TECHNICAL EFFICIENCY OF MAIZE PRODUCTION IN MUNA DISTRICT OF SOUTHEAST SULAWESI." International Journal of Research - Granthaalayah, 8(3), 201-206. https://doi.org/10.29121/granthaalayah.v8.i3.2020.143.

\section{Introduction}

The agricultural sector is the main sector that plays essential roles in employment generation, food security, economic growth, and provision of foreign exchange. In addition, the agricultural sector also drives other economic sectors through its multiplier effect. For this reason, complete, accurate, and up-to-date data on agricultural sector are needed as a reference for the government and stakeholders in planning and designing related policies and programs.

The Province of Southeast Sulawesi has natural resources that are quite potential to be developed, and agriculture is one of the sectors that become development priorities expected to increase economic growth. This is because the majority of people still rely on agriculture as their source of livelihoods. The agricultural sector consists of some sub-sectors including food crops and estate crops. Furthermore, most of the existing agricultural land is utilized by the community to grow a number of major food crops such as rice, sweet potatoes, cassava and maize [1]. 
Maize is the second most important food crop after rice [2]. In order to reduce dependence on rice and to improve food security $[3,4]$, the government of Indonesia has adopted policies and programs in all agribusiness subsystems to increase maize production. In the on-farm subsystem, efforts are directed to increase productivity per unit area of land through the efficient use of production factors. When used efficiently, the production factors of maize farming can result in maximum productivity. The importance of technical efficiency of maize farming is to measure the success of production factors (land size, seeds, fertilizer, pesticides and labor) to obtain maximum productivity. Empirically, estimating efficiency is important to determine the profit that can be obtained by increasing production performance with existing technology [5]. With the existence of technical efficiency, farmers can find out which production factors have not been used efficiently so that they can control it to attain maximum productivity.

Muna District is one of the potential areas for the development of maize farming. Maize is widely cultivated as the main staple food for the community. Maize widely consumed as staple food is glutinous maize. In 2017, maize production in Muna District reached 32,007 tons with the harvested area of 13,159 ha [1]. The adoption of maize technology in Muna Regency is still in the medium category. Department of Agriculture in Southeast Sulawesi Province [6] indicates that farmers still used traditional technology in maize farming, which leads to the low production and productivity. Besides, about $99 \%$ of maize farming is grown in dry land. Meanwhile, the potential for other land such as rice fields has not yet been optimally utilized.

Smallholder maize farmers in Muna District face some challenges such as the fluctuation of their yield, changes in planting time and cropping season [7], and the optimum use of inputs. There is also limited information regarding the efficiency of maize farming and the determinants of maize productivity. This study is conducted to examine the technical efficiency and factors affecting the productivity of maize farming.

\section{Materials and Methods}

This study was carried out in Oelongko Village, Bone Kancitala Sub-district in Muna District. The location was chosen intentionally based on the consideration that the village of Oelongko in Bone Kancitala subdistrict was a maize production center in the district. This study was conducted in May-October 2019. The population of the study was 46 maize farmers living in the study village. Respondents were 32 farmers who were taken using simple random sampling method. The data consisted of primary and secondary data. The data were analyzed using multiple linear regression analysis based on the Cobb-Douglas production function using SPSS version 16 and Stochastic Frontier 4.1c. The Cobb-Douglas function can be stated as follows [8]:

$\mathrm{Y}=\beta_{0} \mathrm{X} 1^{\beta 1} \mathrm{X} 2^{\beta 2} \mathrm{X} 3^{\beta 3} \mathrm{X} 4^{\beta 4}$

The equation can be transformed into multiple linear forms by using the equation as follows:

Where:

$$
\operatorname{Ln} Y=\operatorname{Ln} \beta_{0}+\beta_{1} \operatorname{Ln} X_{1}+\beta_{2} \operatorname{LnX}_{2}+\beta_{3} \operatorname{LnX} X_{3}+\beta_{4} \operatorname{LnX} X_{4}+\beta_{5}
$$

Y : Maize production $(\mathrm{kg})$

$ß_{0} \quad$ : Constant 
$\beta_{\mathrm{i}} \quad$ : Production elasticity of the $\mathrm{i}^{\text {th }}$ production factor $(\mathrm{i}=1,2,3 \ldots)$

$\mathrm{X}_{1} \quad$ : Land Size (ha)

$\mathrm{X}_{2} \quad$ : Seed $(\mathrm{kg})$

$\mathrm{X}_{3} \quad$ : Fertilizer $(\mathrm{kg})$

$\mathrm{X}_{4} \quad$ : Pesticide (liter)

$\mathrm{X}_{5} \quad$ : Labors (man-day)

To determine the significance level of each independent variable regression coefficient toward dependent variable, the coefficient of determination, F-test and t-test were conducted. To determine the value of technical efficiency the formula used is as follows:

$$
E T=\frac{Y i}{Y i^{\prime}}
$$

Where yi is the actual production of the observations and yi' is the alleged stochastic frontier production. Technical efficiency ranges from zero to one or ET value, which is $0 \leq \mathrm{ET} \leq 1$. The value of technical efficiency is categorized as quite efficient if it is $\geq 0.70$ and is categorized as inefficient if it has a value $<0.70$ [9].

\section{Results and Discussions}

\subsection{Analysis of Factors Affecting Maize Production}

Multiple linear regression analysis was used to determine the relationship between independent variables, namely, land size $\left(x_{1}\right)$, seed $\left(x_{2}\right)$, fertilizer $\left(x_{3}\right)$, pesticide $\left(x_{4}\right)$, labor $\left(x_{5}\right)$, and the dependent variable of production $(\mathrm{Y})$. The result is presented in Table 1 as follows:

Table 1: Summary of estimated results of the factors affecting maize production

\begin{tabular}{|l|l|c|c|c|}
\hline No & Variables & $\begin{array}{c}\text { Regression } \\
\text { Coefficient }\end{array}$ & \multicolumn{2}{|c|}{ Partial Test } \\
\cline { 3 - 5 } & & B & T & Sig. \\
\hline & $($ Constant $)$ & 684.05 & 10.086 & 0.000 \\
\hline 1 & Land size $\left(\mathrm{X}_{1}\right)$ & 0.840 & 2.955 & $0.007^{*}$ \\
\hline 2 & Seed $\left(\mathrm{X}_{2}\right)$ & 0.652 & 2.885 & $0.008^{*}$ \\
\hline 3 & Fertilizer $\left(\mathrm{X}_{3}\right)$ & 0.284 & 1.962 & $0.061^{*}$ \\
\hline 4 & Pesticide $\left(\mathrm{X}_{4}\right)$ & 0.412 & 1.508 & $0.144 \mathrm{~ns}$ \\
\hline 5 & Labor $\left(\mathrm{X}_{5}\right)$ & 0.045 & 0.289 & $0.775 \mathrm{~ns}$ \\
\hline & F (Simultaneous Test) & & 12.281 & $0.000^{*}$ \\
\hline & Coefficient of Determination $\left(\mathrm{R}^{2}\right)$ & 0.653 & & \\
\hline
\end{tabular}

Note: $*=$ Significant, $\mathrm{ns}=$ Not Significant

As shown in Table 1, the SPSS output results reveal a significant value of the constants, land size, seeds, fertilizers, and pesticides. The regression model equation can be arranged by looking at the value in column B, and accordingly, in this study the model is presented as follows:

$Y=684.05+0.840 X_{1}+0.652 X_{2}+0.284 X_{3}+0.412 X_{4}+0.045 X_{5}$ 
The coefficient of determination $\left(\mathrm{R}^{2}\right)$ was used to determine the accuracy of the model while identifying the effect of independent variables to the dependent variable using the adjusted $\mathrm{R}^{2}$. Based on table 1 , the value of adjusted $\mathrm{R}^{2}$ is 0.653 . This shows that $65.3 \%$ of the maize production variability in the study area could be explained by the variables of land size, seeds, fertilizer, pesticides and labor, while $34.7 \%$ was affected by other variables not included in the regression model.

The F test was used to determine whether all independent variables (land size, seed, fertilizer, pesticides and labor) included in the model or equation had a simultaneous effect on the dependent variable (production). The results of the analysis of the $\mathrm{F}$ test indicated that the significance value of $\mathrm{F}$ test is $0.000<\alpha 0.1(10 \%)$, so it can be concluded that the variables of land size, seed, fertilizers, pesticides, and labor, jointly has a significant effect on maize production.

T test was used to identify how much the independent variables of land size $\left(x_{1}\right)$, seed $\left(x_{2}\right)$, fertilizer $\left(x_{3}\right)$, pesticide $\left(x_{4}\right)$, and labor $\left(x_{5}\right)$ affected the dependent variable of production (Y). Ttest results can be explained as follows:

The analysis revealed that the variable of land size had a regression coefficient of 0.840 , sig $=$ 0.007. This explained that the use of land size had a significant and positive effect on maize production. The result of the estimated size regression coefficient was 0.840 , which indicated that each $1 \%$ increase in land size would increase the amount of maize production by $0.840 \%$ with the assumption that other variables were fixed.

The analysis revealed that the seed variable had a regression coefficient of 0.652 , sig $=0.008$. It indicated that the seed variable had statistically positive and significant relationship to the amount of maize production. Estimated result of seed regression coefficient was 0.652, which indicated that each additional $1 \%$ of the seeds would increase the amount of production to $0.652 \%$.

The regression coefficient of fertilizer was 0.284 , sig $=0.061$. It indicated that the variables of fertilizer had significant effect on the dependent variable. Variable regression coefficient had positive and significant impact on the level of production of maize with a coefficient of 0.284 indicated that with the addition of $1 \%$ fertilizer would increase production of maize to $0.284 \%$.

The analysis revealed that the pesticide variable had a regression coefficient of 0.412 , sig $=0.144$. Thus, the pesticide variable had no statistically significant effect on the amount of maize production. This could be the impact of the use of pesticides in these farms only as a precautionary measure, so the dosage used was relatively small due to the lack of weed disturbance when cultivated. Therefore, the function of pesticides was not the determining factor on the improvement of production, but only to keep the potential production created by other agricultural inputs which had not decreased.

The analysis revealed that the labor variable had a regression coefficient of 0.045 , sig $=0.775$. It indicated that the labor variable had statistically positive and not significant relationship toward the amount of maize production. 


\subsection{Technical Efficiency}

Technical efficiency was analyzed using the Stochastic Frontier production function model with the Maximum Likelihood Estimate (MLE) estimation method on the frontier 4.1c program. Technical efficiency is the efficiency that connects the actual production and maximum production. A utilization of the production factors can result in maximum production. Technical efficiency is obtained when farming is able to allocate the production factors in such a way that can result in high yields. Technical efficiency is a production process using a combination of a few inputs to produce maximum output. The level of technical efficiency of maize obtained by maize farmers in Bone Kancitala Sub-district in Muna Regency is presented in Table 2. The efficiency values are in the range of 0.3018 to 0.9998 .

Table 2: Degree of technical efficiency of maize farming

\begin{tabular}{|l|c|c|}
\hline $\begin{array}{l}\text { Technical } \\
\text { Efficiency }\end{array}$ & $\begin{array}{c}\text { N } \\
\text { (People) }\end{array}$ & $\begin{array}{c}\text { Percentage } \\
(\boldsymbol{\%})\end{array}$ \\
\hline TE $\leq 0,7$ & 7 & 21,88 \\
\hline TE $>0,7$ & 25 & 78,12 \\
\hline Total & 32 & 100 \\
\hline Minimum TE & \multicolumn{2}{|c|}{0.3018} \\
\hline Maximum TE & \multicolumn{2}{|c|}{0.9998} \\
\hline Average TE & \multicolumn{2}{|c|}{0.72} \\
\hline
\end{tabular}

Table 2 shows the technical efficiency of maize from all farmers in the Sub-district of Bone Kancitala in Muna. It is on average of 0.72. Farmers' technical efficiency is categorized as efficient if its value $\geq 0.70$ and categorized inefficient if its value $\leq 0.70$ [9]. This shows the potential for production obtained from a combination of factors of production. The results showed that the average value of technical efficiency was 0.72 with the lowest value $=0.3018$ and the highest value $=0.9998$. This result indicated that maize farming in the study area was technically efficient.

Based on the average value of technical efficiency of the study, it can be stated that the farmers still had the opportunity to obtain higher potential yields until reaching maximum results as obtained by the most technically efficient farmers. These results indicated that, overall, the farmers still have a chance to improve the technical efficiency on the existing input by 28 percent.

\section{Conclusions and Recommendations}

Factors affecting positive to the product of the maize were land size, seed and fertilizer. The level of technical efficiency of maize obtained by maize farmers in in the study area was 0.72 on average, which indicated that the level of technical efficiency of maize was quite efficient, yet it still had a chance to increase its efficiency by 28 percent. It is suggested to the local government to keep efforts to maintain the technical efficiency by ensuring the availability of production factors and the active involvement of extension officers to provide information on farming practices to farmers. 


\section{Acknowledgements}

The author was grateful to the Head of Oelongko village for his support during the data collection in the village.

\section{References}

[1] BPS Sulawesi Tenggara. Sulawesi Tenggara dalam Angka. Kendari: BPS Sulawesi Tenggara; 2018

[2] Saediman H. Prioritizing commodities in Southeast Sulawesi Province of Indonesia using AHP based Borda count method. Asian Social Science, 2015;11(15):171-179.

[3] Saediman H, Amini A., Basiru R, Nafiu LO. Profitability and value addition in cassava processing in Buton District of Southeast Sulawesi Province, Indonesia. Journal of Sustainable Development, 2015; 8(1);226-234

[4] Saediman H, Aisa S, Zani M, Limi MA, Yusria WO. Food security status of households in a cassava growing village in Southeast Sulawesi, Indonesia. Journal of Agricultural Extension. 2019; 23(1): 199-209.

[5] Islam, KMZ, Bäckman S, Sumelius J. Technical, economic and allocative efficiency of microfinance borrowers and non-borrowers: Evidence from peasant farming in Bangladesh. European Journal of Social Sciences. 2011; 18(3): 361-377

[6] Dinas Pertanian Provinsi Sulawesi Tenggara. Identifikasi pemetaan lahan pangan berkelanjutan di Kabupaten Muna dan Muna Barat. Kendari: Dinas Pertanian Bekerjasama Dengan LPPM UHO; 2017

[7] Saediman H, Lasmin LO, Limi MA, Rianse U, Geo L. Rice farmers' perception of climate variability in South Konawe District of Southeast Sulawesi, International Journal of Scientific and Technology Research, 2020; 9(2): 3128-3132.

[8] Soekartawi. Analisis Usahatani. Jakarta: Universitas Indonesia; 2003

[9] Coelli TJ, Rao DSP, O'Donnell CJ, Battese GE. An introduction to efficiency and productivity analysis. 2nd ed. New York, NY, United States: Springer; 2005.

*Corresponding author.

E-mail address: laode.geo@ uho.ac.id 